\title{
WhatsApp Messaging: Achievements and Success in Academia
}

\author{
Davidivitch Nitza ${ }^{1} \&$ Yavich Roman ${ }^{1}$ \\ ${ }^{1}$ Ariel University, Ariel, Israel \\ Correspondence: Yavich Roman, Ariel University, Ariel, Israel
}

Received: October 5, 2016

Accepted: October 24, 2016

Online Published: November 2, 2016

doi:10.5430/ijhe.v5n4p255

URL: http://dx.doi.org/10.5430/ijhe.v5n4p255

\begin{abstract}
In recent years, there has been a significant rise in the use of technological means in general and in academic teaching in particular. Many programs have been developed that include computer-assisted teaching, as well as online courses at educational institutions. The current study focuses on WhatsApp messaging and its use in academia. Studies have found that class WhatsApp groups serve for communicating with students, nurturing a social atmosphere in the classroom, forming dialogue and collaborations between students, and as a means of learning. The current study explored students' level of achievements and satisfaction as part of a WhatsApp group in a case study of a seminar course, with the aim of investigating whether use of a WhatsApp group as part of guiding an academic seminar will improve achievements in writing the seminar paper. The findings show a significant positive relationship between the achievements of WhatsApp users and their satisfaction, such that the higher the achievements of WhatsApp users the higher their satisfaction. This tool was found to have a strong effect on students' achievements. The current findings illuminate the possibilities offered by technological tools for teaching practice.
\end{abstract}

Keywords: WhatsApp, technology, Achievements, Academia

\section{Introduction}

In recent years, there has been a significant increase and advancement of technology and computer-assisted teaching, both in academia and at schools. It is evident that there is now a new generation of children, whom the literature calls "digital children" and the "network generation", who are surrounded by media and information technologies that include the internet, smartphones, and the media in general (Prensky, 2001).

There is clearly a difference between this generation and those preceding it, manifested both in learning forms and in forms of thinking and cognition. The learning of internet generation children takes a more active form, utilizing hands-on experiencing and specializing in simultaneous task performance, accessing a large amount of information, and connecting with their surroundings and with many circles. According to Brown (2002), the knowledge acquisition of this generation is not linear, rather characterized by "bricolage", i.e., learning based on the consequencies of unprofessional amateur and improvised inquiry.

\section{Theoretical Background}

\subsection{WhatsApp Messaging}

Of all the technological means noted above, the WhatsApp app has become one of the most popular in the market, as evident from its usage by over 350 million users (Tzuk, 2013). WhatsApp is a smartphone app intended for sending instant messages. Message can be sent both personally and in-group form - such that it is possible to communicate with several people simultaneously. People utilize this app due to its low cost, the immediate possibility of holding a fluent conversation, the sense of belonging to a group that creates a feeling of community and family, and the confidentiality maintained, unlike social networks (Church \& de Oliveria, 2013).

\subsection{Integrating WhatsApp in the Educational System and Academia}

Following the incessant use of this app, it is evident that it too has entered the educational system and academia. Previous studies have found that class WhatsApp groups are used for communicating with students, nurturing a social atmosphere in class, forming a dialogue and collaboration between the students, and as a means of learning. Another benefit of this app is the possibility it gives the teacher to become more familiar with the students and to influence student discourse. Moreover, WhatsApp has academic benefits evident in the availability of the teacher, learning that continues outside the classroom, and rapid access to study materials. Nevertheless, there are also 
disadvantages as not all students have smartphones that enable use of the app. Furthermore, there is a large amount of messages and the need to deal with improper language, and finally, students have high expectations that the teacher will answer their questions quickly and effortlessly (Deshen, Buchnik \& Brochson, 2014).

A pilot study on this subject attempted to explore the common phenomenon of class communication in shared teacher-student WhatsApp groups. The study included semi-structured interviews with teachers who use WhatsApp groups together with their students. These interviews examined the pros and cons of these groups and their conduct. The findings show several benefits: Technical benefits - stressing the easy operation of the app, the lack of costs, and the privacy maintained in the group. The interviews show that use of WhatsApp is preferable to other media (e-mail, Facebook, and texting). Educational benefits - evident in the student's feelng of belonging to the class; in addition, the teacher's presence in the group has a positive effect on the conversation between the group participants. Academic benefits - evident in the teacher's availability for academic questions, sending study material by WhatsApp such that it reaches everyone immediately. WhatsApp also lets the student review the material at home and come with additional knowledge beyond the formal classes. Moreover, teachers can correct students' mistakes immediately and add comments. Following use of WhatsApp groups, students feel confident, have someone to ask questions. Even students who do not stand out in class can express themselves with this app without feeling shame and helplessness (Deshen et al., 2014).

\subsection{Use of WhatsApp Groups, Student Achievements and Satisfaction}

In light of previous studies, there seems to be a connection between use of technological means and students' achievements. Previous studies focused on laptops in class, frontal lectures, and e-mail as affecting academic achievements. The current study, unlike the pilot studies mentioned above, focuses on use of WhatsApp groups in guiding seminars, with the aim of conveying instant messages, pictures, videos, and sound bites. Among other things, use of WhatsApp groups expands the interpersonal instructor-student communication and enables availability for questions, scheduling meetings and consultations, thus creating an administrative benefit that contributes to comfortable conduct within the group. Accordingly, the current study examines the relationship between technological means, and in particular WhatsApp, in academia, and academic achievements of students. The relationship will be examined through Nira Hativa's model, which focuses on cognitive aspects that include organization, clarity, concentration, and attention - and emotional aspects, that include interaction with the student, response to questions, caring, respect, and support (Hativa, 2015). Through these aspects, the emotional and the cognitive, the current study will examine how they affect the student's compliance and wish to attend class, level of participation in class, and the need to take an inseparable part in the course of study, as well as the student's satisfaction with use of WhatsApp groups.

The research hypothesis: A positive correlation will be found between the achievements of WhatsApp users and their satisfaction, such that the higher the achievements of WhatsApp users the higher their satisfaction.

\section{Method}

\subsection{Participants}

The research sample consisted of 120 participants, 102 women and 18 men. All the participants were students studying at Ariel University, mostly undergraduate students with a secondary education. The mean age was 24.28 with a range of faculties $(\mathrm{SD}=3.01)$. Participants were sampled on a volunteer basis.

\subsection{Tools}

The current study included a questionnaire designed according to Hativa's (2015) cognitive-emotional model 


\section{A model of Main Teaching DimensionsCategories}

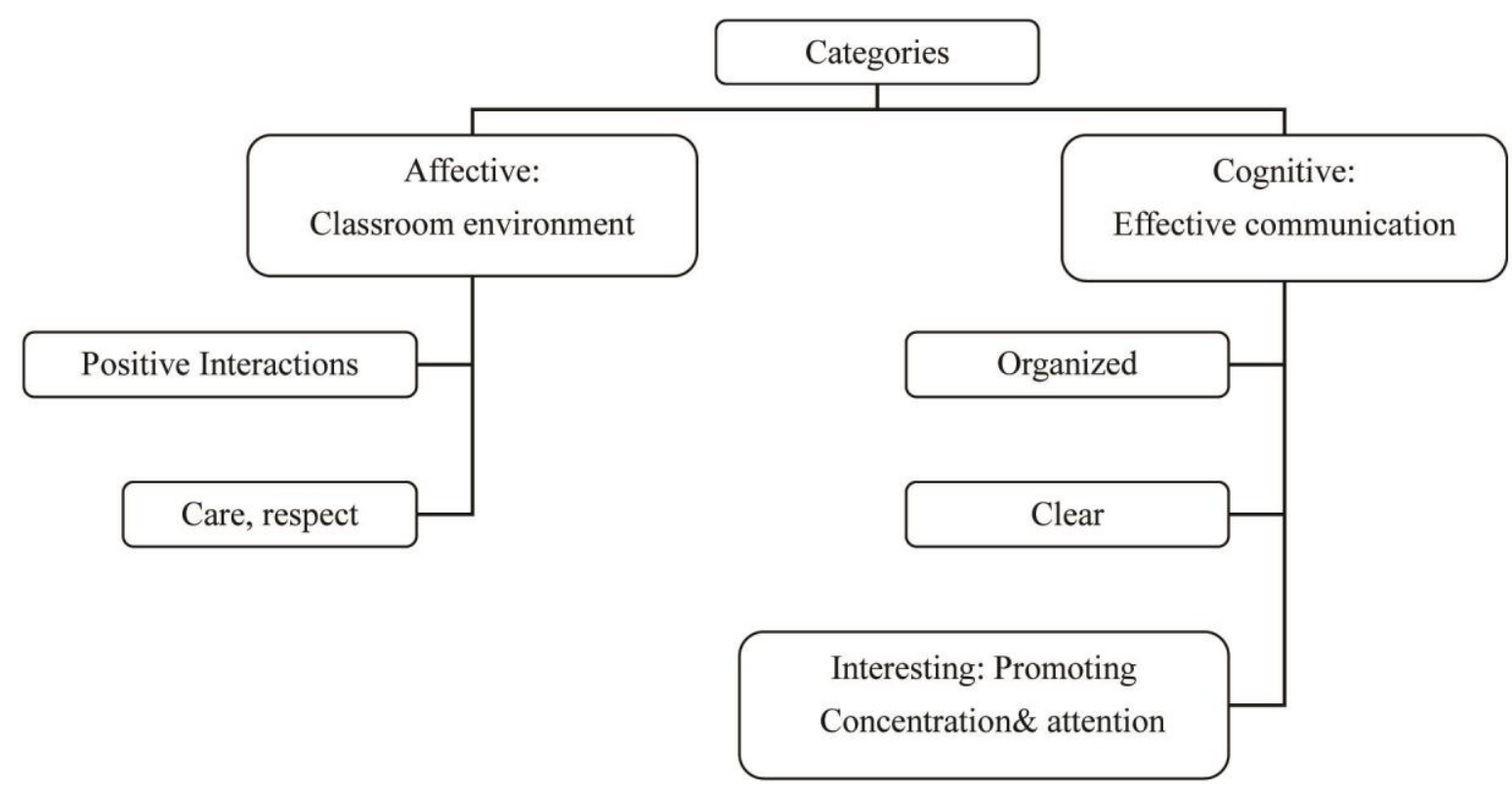

The questionnaire was divided into two aspects:

- The first aspect is the emotional aspect and it examined satisfaction among students with regard to the WhatsApp app and its contribution to improving teaching. Alpha Cronbach reliability for this aspect was $\alpha=0.833$.

For example: To what extent the cooperative groups influenced in organization and success of the course:

- Positive Interactions

- Care, respect

- The second aspect fosued on the cognitive dimension and examined the achievements of students who use the WhatsApp group. Alpha Cronbach reliability for this aspect, as found in the current study, was $\alpha=0.855$. For example: To what extent the cooperative groups influenced In organization and success of the course:

- organization

- clarity

- motivation: promotion of concentration and attention

The satisfaction aspect includes the evaluation of both parts by students: cognitive and emotiaonal parts of the Hativa's model (2015).

- The third aspect fosued on Achievements - To what extent the cooperative groups influenced the academic progress at the end of the semestrial course?

\subsection{Procedure}

The participants were sampled on a volunteer basis and recruited throughout Ariel University. The participants were told that completing the questionnaire is not compulsory and that they can stop at any stage if they feel any encroachment upon their privacy. A consent form was distributed before the participants received the questionnaires, in which participants declared that they were participating of their own free will. The questionnaire was administered throughout the university at times convenient to students in seminar WhatsApp groups and to students who do not use this aide. The research procedure began with a demographic questionnaire (Table 1), followed by a questionnaire on satisfaction with the seminar WhatsApp group (Table 2), as manifested in emotional and cognitive aspects (Figure 1).. 


\section{Results}

Table 1. Sociodemographic variables

\begin{tabular}{|c|c|c|c|}
\hline Variable & & $\mathrm{N}$ & $\%$ \\
\hline \multirow[t]{2}{*}{ Sex } & Male & 18 & 14.4 \\
\hline & Female & 102 & 81.6 \\
\hline \multirow[t]{3}{*}{ Religiosity } & Secular & 57 & 45.6 \\
\hline & Religious & 45 & 36 \\
\hline & Other & 18 & 14.4 \\
\hline \multirow[t]{4}{*}{ Marital status } & Single & 91 & 72.8 \\
\hline & In a relationship & 13 & 10.4 \\
\hline & Married & 15 & 12 \\
\hline & Divorced & 1 & 0.8 \\
\hline \multirow[t]{2}{*}{ Education } & Academic & 118 & 94.4 \\
\hline & Other & 2 & 1.6 \\
\hline \multirow[t]{4}{*}{ Year of studies } & Year 1 & 25 & 20 \\
\hline & Year 2 & 19 & 15.2 \\
\hline & Year 3 & 73 & 58.4 \\
\hline & Year 4 & 3 & 2.4 \\
\hline
\end{tabular}

Table 2. Descriptive statistics of the research variables

\begin{tabular}{ccccc}
\hline Variable & $\mathrm{N}$ & Range & Mean & Standard deviation \\
\hline Age & 120 & $47-20$ & 24.28 & 3.01 \\
\hline Achievements & 120 & $4-1$ & 2.71 & 0.70 \\
\hline Satisfaction & 120 & $4-1$ & 2.83 & 0.70
\end{tabular}

To examine the hypothesis that a positive correlation would be found between the achievements of WhatsApp users and their satisfaction, a Pearson correlation was performed. As hypothesized, a strong positive correlation was found $(\mathrm{rp}=0.819, \mathrm{p}<0.01)$, such that the higher the achievements of WhatsApp users the higher their satisfaction (Figure 1).

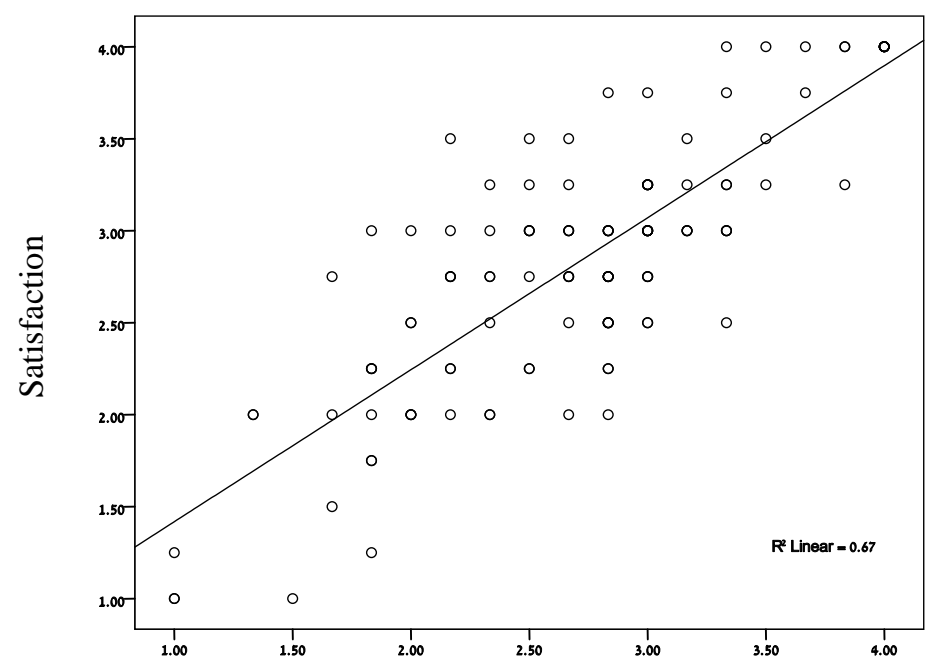

Achievements

Figure 1. Pearson correlation between achievements and satisfaction among WhatsApp users 
In summary, this study examines achievements among students based on a case study of a single university, and the relationship between students' achievements and their satisfaction with a WhatsApp group. This tool clearly contributes significantly to success and to high satisfaction among students, and it can serve as an aide in courses taught for a degree. Therefore, the research recommendation is to integrate this tool in curricula, both in regular schools and in academia and to strengthen ties between all members of the group in order to create as comfortable and positive a study atmosphere as possible.

\section{Discussion}

The current study examined achievements among students and their satisfaction as part of a WhatsApp group in a seminar course, based on cognitive items and emotional items from Hativa's (2015) model. The reseach hypothesis was that a positive correlation would be found between the achievements of WhatsApp users and their satisfaction, such that the higher the achievements of WhatsApp users the higher their satisfaction.

Consistent with the research hypothesis, a strong significant positive correlation was found between the achievements of the WhatsApp users and their satisfaction. The research findings can be explained based on the research of Deshen et al. (2014), who found that class WhatsApp groups are an instrument for communication between students and teachers. Furthermore, these groups nurture a social atmosphere in class, create a dialogue and collaboration. Moreover, WhatsApp groups serve as a learning means, producing a significant benefit as teachers can get to know their students well and influence students' discourse. In addition, the WhatsApp app has academic benefits manifested in the availability of the teacher, continued learning beyond the class limits, and rapid access to the study materials.

Another foundation enhancing the findings indicating a positive correlation with student satisfaction in the current study, may be explained by Church and de Oliveria (2013) who contended that the WhatsApp app contributes to the sense of belonging to a group and creates a feeling of community and family among its users.

As stated, according to Deshen et al. (2014), this app has academic benefits that are manifested in the teacher's availability for study questions and the possibility of sending study material by WhatsApp such that it reaches everyone immediately. Notably, use of the WhatsApp group also enables the student to review the material at home and to bring additional knowledge beyond the official school hours. Moreover, teachers can correct student mistakes on the spot and offer comments. As stated, it is evident that due to use of WhatsApp groups students feel a sense of confidence that they have an address for any question or request they may have.

\subsection{Research Limitations}

Several limitations were found in the current study. First, the number of participants was relatively limited and the number of men was not equal to the number of women, with women constituting a significant majority, which might have caused a bias in the research results. Another limitation is the lack of many studies on this topic, since the app is relatively new in the market in general and in the educational field in particular.

\subsection{Research Significance}

The current study can help raise awareness of possible use of the WhatsApp app for study purposes, which include academic usage for seminars and other courses. This app also shortens the distance between the instructor and the student and enhances their interpersonal connection. Furthermore, the WhatsApp group can also contribute to high achievements as a result of positive interaction between all group members, who help each other, share materials, and update members.

In order to overcome the reseach limitations it is possible to conduct several further studies. First, it is possible to overcome the interfering variables that obstructed the research process, by allocating a permanent quiet place in order to keep the process uniform and standard. The number of men and women should be balanced, and the number of participants raised. The contribution of this app should be further explored by additional means, and other variables capable of affecting its contribution to academia should be added.

\section{Acknowledgements}

The authors wish to thank Hilla Asraf and Roni Ashchar, undergraduate's students in social science at Ariel University for their assistance in the data collection for this study. 


\section{References}

Beyth-Marom, R., Saporta, K., \& Caspi, A. (2005). Synchronous vs. Asynchronous Tutorials: factors affecting students' preferences and choices. Journal of Research on Technology in Education, 37(3), 245-262. http://dx.doi.org/10.1080/15391523.2005.10782436

Blau, I (2011). E-Collaboration Within, Between, and Without Institutions: Towards Better Functioning of online groups through networks. International Journal of e-Collaboration, 7, 22-36. http://dx.doi.org/10.4018/jec.2011100102

Blau, I. \& Barzel-Rubin, A. (2013). Assisting learning disabilities and empowering excellence by "clickers" and interactive whiteboards. Presented at 15th Biennial EARLI Conference for Research in Learning and Instruction. TUM School of Education, Technical University Munich, Germany.

Blau, I., \& Peled, Y. (2012). Teachers' openness to change and attitudes towards ICT: Comparison of Laptop per Teacher and Laptop per Student programs. Interdisciplinary Journal of E-Learning and Learning Objects, 8, 73-82.

Blau, I., Peled, Y., \& Nusan, A. (2014). Technological Pedagogical and Content Knowledge (TPACK) in One-to-One Classroom: Teachers Developing "Digital Wisdom". Interactive Learning Environments. http://dx.doi.org/10.1080/10494820.2014.978792

Brown, J. S. (2002). Growing up digital: How the web changes work, education, and the ways people learn. United States Distance Learning Association Journal, 16(2), Retrieved March 1, 2009 from: http://www.usdla.org/html/journal/FEB02_Issue/article01 .html

Campbell, A. B., \& Pargas, R. P. (2003). Laptops in the classroom. In ACM SIGCSE Bulletin, 35(1), 98-102. http://dx.doi.org/10.1145/792548.611942

Campbell, W.J. \& Robinson, N.M. (1981). The quality and teaching costs of alternate arrangements made for rural senior secondary school students in south-east Queensland, Unpublished report to Education Research and Development Committee.

Caspi, A. \& Blau, I. Soc Psychol Educ. (2011). Collaboration and psychological ownership: how does the tension between the two influence perceived learning? Social Psychology of Education, 14(2), 283-298. http://dx.doi.org/10.1007/s11218-010-9141-z

Church, K., \& de Oliveira, R. (2013, August). What's up with WhatsApp? Comparing mobile instant messaging behaviors with traditional SMS. In Proceedings of the 15th international conference on Human-computer interaction with mobile devices and services (pp. 352-361). ACM.

Deshen, M., Buchnik, D. \& Brochson, S. (2014). Bar-Ilan University. [Hebrew] http://meital.iucc.ac.il/conf2014/Meital_Conference_BL14_part_1.pdf

Eitan, N. (2006). Adjustment to teaching and learning in a computer-assisted virtual environment. Dapey Yozma. [Hebrew]

Feinmesser, O. (2000). Although you don't see any eyes. Ha'aretz. Distance Learning Supplement. [Hebrew]

Gehlen-Baum, V., \& Weinberger, A. (2012). Notebook or Facebook? How Students Actually Use Mobile Devices in Large Lectures. In: A. Ravenscroft, S. Lindstaedt, C. D. Kloos, \& D. Hernández-Leo (Eds.), 21st Century Learning for 21st Century Skills (Volume 7563) (pp. 103-112). Berlin Heidelberg: Springer-Verlag. http://dx.doi.org/10.1007/978-3-642-33263-0_9

Gila Kurtz (Center for Academic Studies), Hagit Miescher-Tal (The Open University, Oranim Academic College, Center for Academic Studies). Personal mobile means in lectures: Uses and implications for the learning process [Hebrew] http://www.openu.ac.il/innovation/chais2014/download/F2-3.pdf

Grimes, M., \& Warschauer, M. (2008). Learning with laptops: A multi-method case study. Journal of Educational Computing Research, 38, 305-332. http://dx.doi.org/10.2190/EC.38.3.d

Hativa, N. (2015). What does the research say about good teaching and excellent teachers? Hora'ah Ba'academya, 5, 50-55. [Hebrew]

Karniel, M. (2003). Communities of learnings on the net. Electronic version: http://www.edu-negev.gov.il/tapuz/motytp/elr

Kozma, R. B. (Ed.). (2003). Technology, innovation and educational change: A global perspective. Eugene, OR: 
ISTE.

Kurtz, G. (2014). In: The learning person in the technological era (pp. 169-176). Open University and Shaham. [Hebrew]

Levin, T., Robnik, B. \& Amiad, R. (1981). How do students perceive the academic-social atmosphere in their classrooms. Iyunim Bechinuch, 29, 87-96. [Hebrew]

Livny, E. \& Yair, Y. (2014). Comparison of remote teaching styles employed during video-based teaching sessions and frontal classes at the Open University of Israel. In: The learning person in the technological era (pp. 77-85). Open University and Shaham. [Hebrew]

Prensky, Marc. (October, 2001) Digital Natives, Digital Immigrants http://www.marcprensky.com/writing/Prensky\%20-\%20Digital\%20Natives,\%20Digital\%20Immigrants\%20-\%2 0Part1.pdf

Royer, R. (1997). Teaching on the internet: Creating a collaborative project. Learning and Leading with Technology, 25(3), 6-11.

Silvernail, D. L. (2011). A middle school One-to-One Laptop program. Maine: Maine Education Policy Research Institute.

Spector-Levy, O. \& Granot Gilat, Y. (2012). The contribution of learning with laptops to the development of learning skills and information literacy among junior high school students. In: Y. Eshet-Alkalay, A. Caspi, S. Eden, N. Geri, Y. Yair, \& Y. Kalman (Eds.), The learning person in the technological era (pp. 183-190). Raanana: Open University. [Hebrew]

Tzuk, A. (2013). WhatsApp has reached 350 million active users per month. Calcalist, 23 October. http://www.calcalist.co.il/internet/articles/0,7340,L-3615097,00.html

Yan, Z. "The psychology of e-learning: Why, what, and how? In Bourne John and Janet C. Moore (Eds). Elements of Quality Online Education: Into the Mainstream, Volume 5 in the Sloan-C series (2004). 